\title{
STRATEGI PEMASARAN PT. ALLIANCE VAST TOURS TERHADAP WISATAWAN PENGGUNA JASA PERJALANAN
}

\author{
I Putu Pradipa Artawan \\ I Made Kusuma Negara \\ Luh Gede Leli Kusuma Dewi \\ E-mail : iputupradipaartawan@yahoo.com \\ PS. S1 Industri Perjalanan Wisata \\ Fakultas Pariwisata UNUD
}

\begin{abstract}
ABSTRACK
Indonesia especially Bali has a huge potential in the field of tourism. It can be seen from a wide range of beautiful natural scenery, culture, history of the nation, festivals and ceremonies are unique, different kinds of art and crafts, and a number of very attractive place for tourists throughout the year.

The study aims is to determine the marketing strategy of the company's tour packages PT. Vast Alliance Tour who can be success to attract tourists to use the services at PT. Vast Alliance Tour. The analysis using SWOT to determine what the is right strategy which can be used to market package of PT. Vast Alliance Tour.

This study led to the conclusion that that the marketing strategies undertaken by PT. Vast Alliance Tour in promoting its products through website, brochures, and sales calls. Products offered by PT. Vast Alliance Tour package in the form of packages like rafting, water sports, cruise, spa, and and much more. Strategy undertaken in this study using the SWOT analysis is to combine the strengths and opportunities that can cover the weaknesses and threats that exist in the relevant product market.
\end{abstract}

Keywords: Marketing of Tourism, Travel Industry.

\section{PENDAHULUAN}

Indonesia yang pada khususnya yaitu Bali memiliki potensi yang cukup besar dalam bidang pariwisata. Ini dapat dilihat dari keindahnya berserta berbagai macam pemandangan alam, kebudayaan, sejarah bangsa, festival dan upacara-upacara yang unik, bermacam seni lukis dan kerajinan tangan, dan banyaknya pilihan tempat yang menarik para wisatawan sepanjang tahun untuk berlibur. Hal ini terjadi berkat adanya kerja keras dari kerja sama pihak-pihak terkait dalam menciptakan kemanan dan tentunya memberikan rasa aman bagi wisatawan untuk berkunjung ke Bali. Dan juga langkah-langkah baik yang di ambil pemerintah sebagai penyediakan fasilitas accessibility, yaitu sarana dan prasarana perhubungan, sehingga memungkinkan wisatawan mengunjungi suatu daerah tujuan wisata seperti sarana transportasi. Di Bali, Bandara Internasional Ngurah Rai sebagai sarana pintu masuk bagi para wisatawan yang menggunakan jasa angkutan udara yang datang dari berbagai daerah di Indonesia dan dari berbagai negara di dunia. Selain itu untuk pelabuhan Gilimanuk, Benoa dan Padang Bai sarana pintu masuk bagi para wisatawan yang menggunakan jasa angkutan laut yang datang dari berbagai daerah di Indonesia dan dari berbagai negara di dunia.

Alat transportasi ataupun akomodasi yang paling dominan yang digunakan oleh wisatawan setibanya di tempat tujuan adalah transportasi darat, baik itu bus, sepeda motor dan mini bus atau mobil pribadi. Karena transportasi atau pengangkutan diperlukan untuk menentukan antara jarak dan waktu dalam melakukan perjalanan sehingga menjadi salah satu unsur utama langsung dalam tahap 
dinamis gejala-gejala pariwisata. Dengan banyaknya minat ataupun kebutuhan pariwisata tentang transportasi dan karena produksi mobil atau bus kini semakin meningkat terus di satu pihak kegemaran orang untuk bepergian dengan alat transportasi mobil atau bus makin bertambah luas di lain pihak dalam kurun waktu 20-30 tahun statistik perjalanan menunjukkan bahwa jumlah orang bepergian dengan mobil atau bus makin bertambah banyak juga dan karenanya mobil atau bus merupakan alat atau perlengkapan transportasi dalam bidang pariwisata yang sangat prinsip. Hal ini disebabkan oleh dua faktor yang menonjol, yaitu pertama karena mobil atau bus dapat dipergunakan secara praktis sebagai alat transportasi untuk mencapai daya tarik yang tidak bisa dicapai dengan alat transportasi darat lainnya. Kedua karena mobil atau bus rencana atau plann perjalanan tidak hanya semata-mata ditentukan oleh jaringan alat transportasi lainnya. Salah satu PT. Alliace Vast sebagai industri yang bergerak dalam bidang penyedia transportasi dan akomodasi dimana penulis ingin melakukan suatu penelitian untuk mengetahui bagaimana strategi pemasaran yang dilakukan oleh PT. Alliance Vast untuk menarik wisatawan.

\section{TINJAUAN PUSTAKA}

Menurut Rangkuti (2001), Strategi merupakan suatu alat yang dipergunakan untuk mencapai tujuan perusahaan dalam kaitannya dengan tujuan jangka panjang, program tindak lanjut, serta prioritas alokasi sumber daya"

Menurut Wahab (1997) pemasaran pariwisata merupakan proses manajemen yang dilakukan oleh suatu industri pariwisata untuk menentukan wisatawan sesuai dengan motivasi, kebutuhan dan keinginan wisatawan kemudian dapat merumuskan suatu produk yang sesuai untuk mendapatkan kepuasan yang optimal dari wisatawan.

Menurut Fandy Tjiptono (2004), bauran pemasaran merupakan tolak ukur yang dipakai untuk digunakan dalam suatu perusahaan agar terbentuk karakteristik barang/jasa yang ditawarkan kepada pelanggan

Menurut Yoeti (2001) pengertian wisatawan seseorang yang melakukan suatu perjalanan dan memasuki wilayah yang bukan daerah asalnya dengan maksud tujuan tertentu, asalkan bukan untuk menetap atau untuk melakukan suatu usaha.

Menurut Sihite (2000) Biro Perjalanan Wisata adalah perusahaan yang bergerak di baidang pariwisata yang melayani suatu permintaan, mengatur transportasi, akomodasi dan jasa-jasa lainnya yang diperlukan wisatawan di daerah tujuan wisata.

\section{METODE PENELITIAN}

Penelitian ini dilakukan di PT Alliance Vast Tour beralamatkan di Jl. Ahmad Yani Kav.3 No. 62 Denpasar - Bali. Pengumpulan data dari penelitian ini dilakukan dengan cara observasi, wawancara secara terstruktur, dan studi kepustakaan. Penelitian ini merupakan penelitian kualitatif deskriftif yang hanya berbentuk suatu penjelasan yang menggambarkan keadaan, proses atau peristiwa tertentu. Teknik analisis yang digunakan adalah teknik analisis SWOT yang berfokus pada strategi pemasaran PT. Alliance Vast dalam menarik wisatawan untuk menggunakan jasa PT. Alliance Vast Tour.

\section{HASIL DAN PEMBAHASAN}

\section{Strategi SO}

1. Meningkatkan dan mengembangkan produk yang diminati wisatawan dan meningkatkan pelayanan dengan menggunakan sarana teknologi dan komunikasi yang ada.

2. Meningkatkan promosi terhadap pasar sasaran dengan menawarkan produk yang beraneka ragam dan inovatif dengan memanfaatkan komponen marketing mix PT. Alliance Vast Tour yang baik, seperti meningkatkan pemanfaatan saluran distribusi yang ada.

3. Meningkatkan kerjasama yang lebih baik dengan hotel berbintang, restaurant, dan travel agent berserta pelayanan jasa menyewakan transportasi yang telah terjalin selama ini dan berupaya membina kerjasama baru dengan industry pariwisata lainnya.

\section{Strategi ST}

1. Mempertahankan harga yang pantas sesuai dengan keinginan konsumen dan kualitas produk untuk memenangkan persaingan.

2. Meningkatkan kualitas pelayanan dengan memanfatkan sumber daya dan fasilitas yang dimiliki perusahaan untuk bisa 
menarik calon pelanggan yang banyak karena pelanggan sekarang lebih selekif.

3. Tingkatkan promosi ke Negara asal wisatawan dengan pemanfaatan kerjasama dengan biro perjalanan setempat untuk memberikan pemahaman akan situasi keamanan dan politik didaerah tujuan wisata dan jaminan keamanannya.

4. Lebih meningkatkan kerjasama dengan biro perjalanan yang telah terbina di dalam negeri maupun di luar negeri dan industry perjalanan lainnya untuk bisa memenangkan persaingan dengan banyaknya biro perjalanan wisata travel agent di Bali.

\section{Strategi WO}

1. Mempromosikan harga dengan menginformasikan produk yang baik.

2. Menjaga hubungan baik dengan beberapa perusahaan transportasi yang ada. Selain itu, mengadakan pembaharuan terhadap alat-alat kantor yang rusak.

3. Meningkatkan kualitas sumber daya manusia dengan mengadakan pelatihan terutama pada karyawan baru untuk meningkatkan pelayanan pada wisatawan dengan meningkatkan minat wisatawan terhadap produk kita dan karyawan juga mampu memanfaatkan media komunikasi yang ada.

4. Meningkatkan mutu pelayanan pada wisatawan untuk meningkatkan kepuasan wisatawan.

\section{Strategi WT}

1. Memperluas segmen pasar dan meningkatkan promosi dengan pencetakan brosur dan lainnya untuk bisa memenangkan persaingan dengan biro perjalanan lain yang ada di Bali.

2. Menjaga mutu produk dan pelayanan.

3. Peningkatan kualitas sumber daya manusia melalui pelatihan terutama bagi karyawan baru untuk bisa memberikan pelayanan yang lebih baik dalam menghadapi pelanggan yang lebih selektif didalam memilih produk wisata dan mampu memberikan pemahaman pada calon wisatawan ataupun pelanggan akan kondisi keamanan, politik, dan lalu lintas sehingga mereka merasa aman dan nyaman dalam melakukan perjalanannya.

\section{Matrik SWOT Analisis}

\begin{tabular}{|c|c|c|}
\hline & $\begin{array}{l}\text { Strengths (S) } \\
\text { 1. Produk yang ditawarkan } \\
\text { beragam. } \\
\text { 2. Kemampuan melakukan } \\
\text { Sales Promotion } \\
\text { 3. Karyawan yang bekerja } \\
\text { berpengalaman. } \\
\text { 4. Memiliki harga yang } \\
\text { bersaing. } \\
\text { 5. Adanya suatu prosedur } \\
\text { pelayanan yang bermanfaat } \\
\text { bagi karyawan maupun } \\
\text { wisatawan }\end{array}$ & $\begin{array}{l}\text { Weaknesse (W) } \\
\text { 1. Wisatawan yang kurang } \\
\text { mengetahui produk yang } \\
\text { ditawarkan. } \\
\text { 2. PT. Alliance Vast Tour belum } \\
\text { memiliki alat transportasi } \\
\text { sendiri. } \\
\text { 3. Masih ada beberapa karyawan } \\
\text { yang tidak disiplin pada jam } \\
\text { masuk kerja. }\end{array}$ \\
\hline $\begin{array}{l}\text { Opportunity }(\mathbf{O}) \\
\text { 1. Terbinanya } \\
\text { kerjasama dengan } \\
\text { biro perjalanan } \\
\text { wisata dan } \\
\text { akomodasi } \\
\text { pariwisata } \\
\text { 2. Banyaknya } \\
\text { asosiasi biro } \\
\text { perjalanan yang } \\
\text { sangat membantu }\end{array}$ & $\begin{array}{l}\text { Strategi SO } \\
\text { 1. Meningkatkan dan } \\
\text { mengembangkan produk } \\
\text { yang diminati. } \\
\text { 2. Meningkatkan } \\
\text { pemanfaatan saran media } \\
\text { untuk promosi. } \\
\text { 3. Meningkatkan kerjasama } \\
\text { yang lebih baik dengan } \\
\text { pelaku industri pariwisata }\end{array}$ & $\begin{array}{l}\text { Startegi WO } \\
\text { 1. Mempromosikan harga } \\
\text { dengan menginformasikan } \\
\text { produk yang baik. } \\
\text { 2. Meningkatkanm engadakan } \\
\text { pelatihan kepada karyawan } \\
\text { baru } \\
\text { 3. Meningkatkan mutu pelayanan }\end{array}$ \\
\hline
\end{tabular}




\begin{tabular}{|c|c|c|}
\hline $\begin{array}{l}\text { perkembangan } \\
\text { perusahaan. } \\
\text { 3. Adanya } \\
\text { peningkatan } \\
\text { sarana teknologi } \\
\text { dan komunikasi. }\end{array}$ & & \\
\hline $\begin{array}{l}\text { Threats (T) } \\
\text { 1. Pesatnya } \\
\text { perkembangan } \\
\text { Biro Perjalanan } \\
\text { wisata maupun } \\
\text { cabang biro } \\
\text { perjalanan } \\
\text { wisata di Bali } \\
\text { 2. Kemacetan } \\
\text { lalulintas yang } \\
\text { sering terjadi. } \\
\text { 3. Situasi politik } \\
\text { dan keamanan di } \\
\text { Indonesia yang } \\
\text { kurang stabil. }\end{array}$ & $\begin{array}{l}\text { Strategi ST } \\
\text { 1. Mempertahankan harga } \\
\text { yang pantas sesuai dengan } \\
\text { keinginan konsumen. } \\
\text { 2. Meningkatkan mutu dan } \\
\text { kualitas pelayanan yang } \\
\text { baik. } \\
\text { 3. Meningkatkan promosi } \\
\text { ke Negara asal wisatawan. }\end{array}$ & $\begin{array}{l}\text { Strategi WT } \\
\text { 1. Menjaga mutu produk dan } \\
\text { pelayanan. } \\
\text { 2. Peningkatan kualitas sumber } \\
\text { daya manusia yang } \\
\text { professional. } \\
\text { 3. Menigkatkan kegiatan } \\
\text { promosi dan kemukakan } \\
\text { kelebihan PT. Alliance Vast } \\
\text { Tour pada setiap publikasi }\end{array}$ \\
\hline
\end{tabular}

\section{SIMPULAN DAN SARAN Simpulan}

Dari pembahasan mengenai strategi pemasaran paket wisata PT. Alliance Vast Tour berdasarkan analisis SWOT yang menganalisis mengenai Strengths ( kekuatan), Weaknesses ( kelemahan), Opportunities ( peluang ), dan Threats ( ancaman) terhadap unsur-unsur marketing mix pada pemasaran PT. Alliance Vast Tour, maka dapat diambil kesimpulan sesuai analisis SWOT strategi pemasaran yang diterapkan pada PT. Alliance Vast Tour yaitu :

1. Produk

Strategi produk yang harus diterapkan PT. Alliance Vast Tour adalah meningkatkan dan mengembangkn produk yang diminati wisatawan yang berinovasi baik dengan penciptaan produk sendiri maupun dengan kombinasi produknya dengan produk jasa wisata lain dan meningkatkan pelayan sehingga PT. Alliance Vast Tour memenangkan persaingan dengan travel lain yang ada di Bali.

2. Harga

Dari segi harga, strategi yang diterapkan adalah menetapkan dan mempromosikan harga, dan kualitas produk yang baik. Kualitas produk tersebut telah terjaga dan hendaknya dipertahankan dengan pemanfaatan proses, bukti fisik dalam meningkatkan kualitas pelayanan sebagai cermin atas harga produk.

3. Saluran Distribusi

PT. Alliance Vast Tour memiliki saluran distribusi yang baik dengan adanya kontrak kerjasama dengan usaha wisata lainnya seperti : travel agent, hotel, restaurant, dan penyedia jasa transportasi dan usaha atraksi lainnya. Strategi yang harusnya dilakukan yakni menjaga baik beserta meningkatkan jalinan kerjasama terhadap travel agent, hotel, restaurant, dan penyedia jasa transportasi dan industry lainya serta menjaga pemahaman akan hak dan kewajiban masing-masing dalam meningkatkan mutu pelayanan wisatawan.

4. Promosi

Strategi promosi dengan sales promotion dan meeting service ditingkatkan dengan memanfaatkan saluran distribusi yang ada pemanfaatan sarana teknologi dan komunikasi sebagai media promosi 
dengan mengemukakan kelebihan PT. Alliance Vast Tour.

5. Personel

PT. Alliance Vast Tour mempunyai karyawan yang cukup handal dalam bidangnya yang mampu memberikan layanan yang baik dan menjaga hubungan antara PT. Alliance Vast Tour, saluran distribusi dan wisatawan. Strategi personal selalu dijaga dan ditingkatkan dengan peningkatan kualitas sumber daya manusia yang professional.

6. Bukti fisik

PT. Alliance Vast Tour memiliki bukti fisik yang mendukung usahanya seperti bangunan dan sarana sarana didalamnya, seragam karyawan serta sarana trasportasi. Bukti fisik ini harus dijaga hubungan baiknya dengan perusahaan transportasi yang ada dan mengadakan pembaharuan terhadapa alat-alat kantor yang rusak.

7. Proses

Dalam menjalankan usahanya PT. Alliance Vast Tour memiliki suatu proses yang tertuang secara tertulis yang dijadikan pedoman dalam persiapan pelayanan serta selalu mengevaluasi kembali setiap mulai adanya kualitas pelayanan yang menurun sehingga mampu menopang hubungan usaha PT. Alliance Vast Tour dengan penyedia wisata lainya serta kepada wisatawan.

\section{Saran}

Berdasarkan hasil dan pembahasan yang telah dibuat, adapun saran-saran yang dianggap perlu untuk kemajuan PT. Alliance Vast Tour di masa yang akan dating adalah sebagai berikut :

1. Menjaga hubungan baik dengan perusahaan transportasi yang selama ini telah memenuhi segala keperluan transportasi PT. Alliance Vast Tour dalam memberikan pelayanan kepada wisatawan. Selain itu, ada baiknya PT. Alliance Vast Tour mengusahakan dapat memiliki alat transportasi sendiri seperti halnya biro perjalanan wisata lainnya.

2. Memberikan karyawan baru pendidikan dan pelatihan yang lebih khususnya dalah hal penguasaan bahasa asing agar nantinya untuk pekerjaan di masa yang akan dating tidak terjadi kesalahan. Kompensasi disesuaikan dengan jabatan yang dipegang dengan sesuai dengan waktu kerja serta memberikan insentif bagi karyawan yang melakukan suatu pekerjaan yang lebih inovatif untuk memajukan perusahaan. Hal ini dilakukan agar karyawan menjadi bersemangat dan mau mengerahkan seluruh kemampuan dalam memberikan pelayanan yang baik bagi konsumen.

3. Kualitas pelayanan yang selama ini hendaknya dijaga dan ditingkatkan agar wisatawan puas sehingga hubungan antara PT. Alliance Vast Tour dengan wisatawan maupun pelanggannya akan selalu terbina dengan baik.

\section{DAFTAR PUSTAKA}

Fandy Tjiptono, 2004, Pemasaran Jasa, Bayu Media Malang.

Kotler, Philip. 1994 a. Marketing. Phineche inc, England

Rangkuti, F. 2001. Analisis SWOT Teknik Membedah Kasus Bisnis, PT. Gramedia Pustaka Utama, Jakarta.

Sihite, Richard. 2000. Tourism Industry. Surabaya : SIC.

Wahab, Salah. 1997. Pemasaran Pariwisata. Jakarta: Pradnya Paramita

Yoeti, Oka A. 1993. Pengantar Pariwisata. Jakarta: Angkasa

1996. Pemasaran Pariwisata. Bandung: Angkasa: Bandung. 